\title{
Editorial
}

\section{Transfer Prices - A Reason to Punish}

\author{
Helmut Becker, Deloitte \& Touche, Düsseldorf
}

The significance of Transfer Pricing is increasing rapidly. The tax authorities have rediscovered that area and in a time of low economy with low tax revenues the adjustment of transfer prices seem to become a new source of state income. Therefore, not only the rules on transfer pricing are increasing but also bad habits begin to expand.

Companies producing losses are not beloved. Neither management and shareholders nor the authorities like them; no profits, no taxes. However, the wide-spread conclusion that losses lasting for some time must be caused by incorrect transfer prices is inappropriate. Losses like profits are the result of the entire entrepreneurial activity and a multitude of factors have influence on this result. Transfer prices are only one single factor and not necessarily dominant.

The OECD report clearly objects against comparable profit methods which are comparable loss methods, too. Nevertheless, the authorities like to conclude incorrect transfer prices from losses. Is that a punishment for unsuccessful companies?

This mentality towards losses only looks like a punishment but some states effectively punish after having adjusted the transfer prices. One example-among others-are the United States.

The taxpayer has to apply and to disclose a transfer pricing method in advance but the district director determines whether this method was appropriate. Even if the taxpayer describes the method applied in detail and gives reasons for his choice accompanied by an appropriate documentation the district director can object. If he does so this not only results in adjusted prices with the high risk of double taxation but also in penalties. And these penalties are drastic:

-20 per cent penalty if the adjustment amounts to the lesser of $\$ 5$ Million or 10 per cent of the gross receipts;

-40 per cent penalty if the adjustment amounts to the lesser of $\$ 20$ million or 20 per cent of the gross receipts.

For multinationals with extensive business transactions this in practice means that pricing adjustments very likely are connected with penalties of 40 per cent.

As far as penalties are a compensation for the late payment of taxes on adjusted prices resulting in higher profits they are justified. It is also understood that penalties and fines are an internal matter of each state; each country is permitted to treat its citizens according to its rules. If, however, there is a cross-border effect the community of states will be affected. That part of the penalties which does not compensate late payment or is not connected with intention or negligence but nevertheless is effectively connected with the transfer prices has a cross-border effect. This part of the penalties is so closely connected with the transfer prices and it is so difficult to avoid them that they economically represent a part of the adjusted transfer price. Therefore, the other countries faced with that result by the same transfer price have all reason to have a careful look at what is going on.

They have also a reason to object against excessive penalties economically resulting in higher transfer prices. Article 9 of the OECD Model Treaty only permits adjustments of transfer prices up to that level independent parties would have remunerated. This is the basic view of the arm's length-principle. Nothing in Article 9 permits a country to charge something over and above that level. Therefore, this rule is violated by excessive penalties not justified as interest or by any criminal actions.

For companies doing international business it is already difficult enough to deal with the transfer pricing rules. There is no reason to increase these difficulties by excessive penalties. In the contrary, they should be protected against that. Their home country can provide such protection by - among others - relying on Article 9 of the OECD Model Treaty. Anyway, transfer prices give no reason to punish. 